\title{
PENDIDIKAN PENDERITAAN DALAM KITAB AYUB GUNA MEMBERI SOLUSI PERKARA-PERKARA DUNIA PELAYAN TUHAN
}

\author{
Iis Dahlia Mayasari ${ }^{1 *}$, Chearolina ${ }^{2}$, Suryowati $^{1}$ \\ ${ }^{1,2}$ Sekolah Tinggi Teologi Bethel Samarinda \\ ${ }^{3}$ Sekolah Tinggi Teologi Excelsius \\ *iisdahliamayasari@gmail.com
}

\begin{abstract}
Suffering is pressure that comes from outside of a person and suffering is actually good for that person. The suffering that exists in humans is both unavoidable and inevitable. Research Objectives: What is meant by suffering education? How to provide a solution to the suffering of people who are complaining? How to provide a solution to the suffering of the quarreling person? How to provide a solution to the suffering of those who commit suicide? How does the education of suffering in the book of Ayub provide solutions to the things of God's servant world at GBI KelIR Samarinda? The answer: (1) Education for suffering is education to live in the world. (2) The solution to the complaining person's suffering is: do something with pleasure, and with humility. (3) The solution to the suffering of the quarreling person is: do not always feel right, and listen to advice. (4) A person dares to live in suffering and can accept the reality of life, obey God, is always grateful, and always longs to live in historical peace. (5) Remain, God is the Source of Life, Don't Blame Anyone.
\end{abstract}

Keywords: Education, Suffering, the Book of Job, Complaints, Quarrel, Suicide, God's Servant

\begin{abstract}
Abstrak
Penderitaan adalah tekanan yang datang dari luar diri seseorang dan penderitaan itu sebenarnya baik untuk diri orang tersebut. Penderitaan yang ada pada manusia tidak bisa ditolak dan tidak bisa dihindari. Tujuan Penelitian: Apakah yang dimaksud dengan pendidikan penderitaan? Bagaimanakah memberi solusi tentang penderitaan orang yang bersungut-sungut? Bagaimanakah memberi solusi tentang penderitaan orang yang bertengkar? Bagaimanakah memberi solusi tentang penderitaan orang yang bunuh diri? Bagaimanakah pendidikan penderitaan dalam kitab Ayub memberi solusi perkara-perkara dunia pelayan Tuhan di GBI KelIR Samarinda? Jawabnya: (1) Pendidikan penderitaan adalah pendidikan untuk hidup di tengah dunia. (2) Solusi tentang penderitaan orang yang bersungut-sungut adalah: melakukan suatu hal dengan senang hati, dan rendah hati. (3) Solusi tentang penderitaan orang yang bertengkar adalah adalah: jangan merasa selalu benar, dan mau mendengar nasihat. Seseorang berani hidup menderita dan dapat menerima kenyataan hidup, taat kepada Tuhan, selalu bersyukur, dan selalu rindu hidup damai sejarah. (5) Tetap Bertahan, Allah adalah Sumber Hidup, Jangan Menyalahkan Siapapun.
\end{abstract}

Kata Kunci: Pendidikan, Penderitaan, Kitab Ayub, Sungut-sungut, Bertengkar, Bunuh Diri, Pelayan Tuhan 


\section{PENDAHULUAN}

Harianto GP mengatakan bahwa penderitaan adalah tekanan yang datang dari luar diri seseorang dan penderitaan itu sebenarnya baik untuk diri orang tersebut. Penderitaan yang ada pada manusia tidak bisa ditolak dan tidak bisa dihindari. Karena manusia itu berdosa maka penderitaan itu telah ada dalam diri manusia sejak dilahirkan ke dalam dunia. Penderitaan orang yang percaya kepada Tuhan dengan orang yang tidak percaya kepada Tuhan sangatlah berbeda. Orang yang tidak percaya kepada Tuhan akan menderita karena dunia tetapi orang yang percaya kepada Tuhan Yesus Kristus maka orang itu menderita karena Yesus Kristus. Orang percaya kepada Yesus Kristus yang hidup dan tinggal di Indonesia sangatlah merasakan penderitaan karena Kristus misalnya, dilarang beribadah, gereja ditutup, gereja dibakar dan pendeta difitnah mengajarkan ajaran sesat, bukan hanya pendeta yang mengalami tetapi juga jemaat dan semua orang yang percaya kepada Yesus Kristus yang difitnah dan ditekan dalam segala kehidupannya, bahkan orangorang percaya yang terbunuh. Aplikasinya penderitaan yang dialami pengikut Yesus Kristus di Indonesia adalah benar-benar Amanat Agung. Jadi semua gereja maupun orang-orang percaya dimanapun berada wajib melakukan misi Allah: menjadi saksi Yesus Kristus dan memberitakan Injilnya sampai ke pelosok tanah air Indonesia, terlebih ke pedalaman Indonesia banyak jiwa yang perlu mendapatkan Injil Kristus. ${ }^{1}$

Penderitaan termasuk kenyatan dalam manusia dan dunia. Ukuran sebuah penderitaan bertingkat-tingkat, ada sebuah

\footnotetext{
${ }^{1}$ Harianto GP, Teologi Pastoral (Yogyakarta: Andi, 2019), 93.
}

penderitaan yang ringan ada pula yang berat. Namun peranan seseorang secara langsung juga menentukan berat atau tidaknya tidaknya ukuran penderitaannya. Suatu penderitaan yang dianggap seseorang itu adalah sebuah penderitaan bagi dirinya sendiri namun belum tentu menjadi penderitaan bagi orang lain. Penderitaan akan dialami oleh semua manusia yang ada di dunia karena penderitaan sudah menjadi "resiko" hidup. Tuhan itu adil, bukan saja ia memberikan sukacita, kesenangan dan kebahagian namun juga memberikan penderitaan. Sedangkan penderitaan psikis, penyembuhannya terletak pada kemampuan si penderita dalam menyelesaikan penderitaan psikis yang dialaminya. ${ }^{2}$

Penderitaan pertama, yaitu emosional dan konsekuensi langsung dari ketidaktaatan, diikuti oleh kutukan Tuhan (Kej. 3: 16-19), yang menjanjikan kesakitan, kerja keras dan kematian. Meskipun penderitaan disebabkan oleh dosa (kejahatan moral), itu sendiri bukan moral tetapi kejahatan fisik (atau material), karena Allah itu secara gamblang disajikan dalam Alkitab sebagai miliknya. ${ }^{3}$

Penderitaan seberat apapun ternyata di dalamnya masih ada hal yang dapat manusia lakukan yaitu suatu hal yang tidak dapat dilakukan atau dikerjakan ketika tidak dalam penderitaan (Fil 1:29) "Sebab kepada kamu dikaruniakan bukan saja untuk percaya kepada Kristus, melainkan juga untuk menderita untuk Dia”. Manusia sering melihat bahwa mutiara itu mahal dan indah namun, tanpa tahu bahwa mutiara itu berasal dari sebuah penderitaan yang dialami oleh

${ }^{2}$ Hasan Alwi, Tata Bahasa Baku bahasa Indonesia (Jakarta: Balai Pustaka, 2003), 255.

${ }^{3}$ Sinclair B. Ferguson dan David F. Wright, New Dictionary of Theology (Malang: Literatur SAAT, 1991), 667. 
kerang, ketika pasir memasuki cangkang kerang pasir-pasir itu akan menyakiti tubuh kerang, maka dengan sekeras tenaganya dengan mengeluarkan lendir yang ada di dalam tubuh untuk melindunginya. Dengan adanya hal itu maka terjadilah sebuah pasir yang tajam bagi tubuh kerang dibalut oleh lendirnya lalu menghasilkan mutiara yang indah dan mahal dengan melalui proses yang menyakitkan. ${ }^{4}$

Dari uraian teori tersebut ditemukan fenomena tentang solusi-solusi yang muncul berdasarkan hikmat dunia atau berkaitan dengan kebutuhan pribadi orang yang memutuskannya sebagai berikut: (1) solusi tentang penderitaan, (2) solusi tentang penderitan orang yang bersungut-sungut, dan (3) solusi tentang penderitaan orang yang bertengkar.

Solusi terhadap problem tersebut perlu dijawab dengan kerja penelitian yang bertujuan: (1) Apakah yang dimaksud dengan pendidikan penderitaan?

Bagaimanakah memberi solusi tentang penderitaan orang yang bersungut-sungut?

(3) Bagaimanakah memberi solusi tentang penderitaan orang yang bertengkar? (4) Bagaimanakah memberi solusi tentang penderitaan orang yang bunuh diri? (5) Bagaimanakah pendidikan penderitaan dalam kitab Ayub memberi solusi perkaraperkara dunia pelayan Tuhan di GBI KelIR Samarinda?

\section{METODE}

Metode penelitian adalah kualitatif dengan pendekatan deskriptif. Deskriptif adalah proses pengumpulan data yang memungkinkan peneliti untuk menghasilkan

\footnotetext{
${ }^{4}$ Fengky M, Masalah adalah Berkat (Jakarta: IGM, 2005), 53.
}

deskripsi ${ }^{5}$ tentang bagaimanakah Pendidikan Penderitaan dalam Kitab Ayub dan Menemukan Solusinya berdasarkan Hikmat Pelayan Tuhan di Gereja Bethel Indonesia Keluarga Imamat Rajani. Pengumpulan data menggunakan wawancara dan observasi. Partisipan yang diwawancarai adalah pelayan Tuhan Gereja Bethel Indonesia Keluarga Imamat Rajani Samarinda berjumlah 5 Orang. ${ }^{6}$

\section{PEMBAHASAN}

\section{Pengertian Pendidikan Penderitaan berdasarkan kitab Ayub}

Pada dasarnya, penderitaan adalah segala sesuatu yang menyakitkan dan mengganggu. Dalam rancangan Allah, penderitaan adalah sesuatu yang menuntut seseorang supaya berpikir. Penderitaan adalah alat yang dipakai Allah untuk membuat kita menjadi peka dan yang dipakai Allah untuk mencapai maksud-Nya dalam hidupnya yang tidak bisa terjadi selain lewat pencobaan dan lewat keadaan yang tidak menyenangkan. Penderitaan bisa dalam bentuk kanker atau sakit tenggorokan. Penderitaan bisa berbentuk sakit penyakit atau kehilangan seseorang yang dikasihi. Penderitaan bisa berbentuk kegagalan hidup atau kekecewaan dalam pekerjaan atau dalam studi. Penderitaan bisa berbentuk gosip yang beredar ditempat ia bekerja atau di gereja yang merusak reputasinya yang membawa kesedihan dan kecemasan. ${ }^{7}$

Pendidikan adalah proses berbagi konten dengan orang lain dalam konteks

\footnotetext{
${ }^{5}$ Sugiyono, Memahami Penelitian Kualitatif (Bandung: Alfabeta, 2008), 43-45.

${ }^{6}$ Cek Lexy J. Moleong, Metodologi Penelitian Kualitatif (Bandung: PT Remaja Rosdakarya, 2008).

${ }^{7}$ Ron Lee Davis, Gold in the Making (Thomas Nelson, Nashville, 1983), 17-18.
} 
masyarakat dan komunitas mereka. ${ }^{8}$ Pendidikan merupakan kegiatan politis bersama para peziarah dalam waktu, yang dengan sengaja bersama orang-orang memperhatikan masa kini, warisan masa lampau yang ada di dalamnya, dan kemungkinan masa depan yang menguasai manusia secara utuh dan komunitas. Pendidikan adalah proses pengubahan sikap dan tata laku seseorang atau kelompok orang di usaha mendewasakan manusia melalui upaya pengajaran dan pelatihan: proses, cara, perbuatan mendidik. ${ }^{10}$ Penderitaan adalah keadaan yang menyedihkan yang harus ditanggung. Kegiatan bersama yang sengaja dilakukan dengan memperhatikan masa kini, warisan masa lampau dan masa depan untuk proses pengubahan sikap dan tata laku seseorang atau kelompok melalui pengajaran atau pelatihan guna mendewasakan orang tersebut.

Lebih dalam lagi pendidikan penderitaan berdasarkan kitab Ayub dapat diuraikan sebagai berikut: Ayub 2:10: Tetapi jawab Ayub ke padanya: "Engkau berbicara seperti perempuan gila! Apakah kita mau menerima yang baik dari Allah, tetapi tidak mau menerima yang buruk?"

Ayub dalam teks ini berarti "menerima atau diterima" berasal dari kata קבל qabal berasal dari kata kerja piel imperfect 1st person קבל common plural. Karena dia Piel berarti menggambarkan suatu tindakan (terusmenerus). Imperfect menyatakan perbuatan yang akan (belum) selesai, ini bisa merujuk pada perbuatan yang terus-menerus atau

\footnotetext{
${ }^{8}$ Robert W. Pazmino, Fondasi Pendidikan Kristen: Sebuah Pengantar dalam Perspektif Injili (Jakrta: BPK Gunung Mulia, 2012),118.

${ }^{9}$ Thomas H. Groome, Pendidikan Agama Kristen (Jakarta: BPK Gunung Mulia, 2011), 30.

${ }^{10}$ Hasan Alwi, Tata Bahasa Baku bahasa Indonesia, 263.
}

berulang-ulang dilakukan.. Jamak berarti menyatakan luasnya (tempat,waktu), intensitas atau keadaan tersebut intensive plural, dan keagungan yang ada kaitannya dengan jamak intensitas. Makna keagungan menunjuk hanya pada nama Allah.

Penderitaan yang dialami oleh Ayub merupakan kekuatan karakternya. Karakter yang baik itu adalah integritas dan itu merupakan salah satu kunci keberhasilan bagi seorang Ayub. Karismanya dapat menghantar dirinya mencapai puncak dan dapat bertahan di puncak. ${ }^{11}$ Maxwell mengatakan bahwa hanya melalui karakter yang baik akan memiliki reputasi yang kuat, baik di hadapan Allah maupun di depan orang-orang yang dipimpinnya. ${ }^{12}$ Begitulah yang dialami oleh sosok Ayub.

Jadi manusia sebagai ciptaan Allah tetap menerima setiap penderitaan yang datang dalam kehidupannya. Karena selama manusia masih di dalam dunia, penderitaan akan terus-menerus dirasakan dan selama manusia di dalam dunia penderitaan ini belum selesai. Penderitaan yang manusia alami bukan saja hanya karena dosa tetapi merupakan ujian dari Tuhan agar manusia mengetahui keagungan Tuhan Allah.

\footnotetext{
${ }^{11}$ Jakoep Ezra, Success Through Character (Yogyakarta : Andi, 2006), 1.

${ }^{12}$ John C. Maxwell, Mengembangkan Kepemimpinan di dalam Diri Anda (Jakarta: Binarupa Aksara, 1995), 41.
} 


\section{Solusi tentang Penderitaan Orang yang Bersungut-sungut}

Tabel 1. Solusi tentang Penderitaan Orang yang Bersungut-sungut

\begin{tabular}{|c|c|}
\hline Fokus: & Sub Fokus \\
\hline \multirow{4}{*}{$\begin{array}{l}\text { Bagaimanakah solusi tentang } \\
\text { penderitan orang yang } \\
\text { bersungut-sungut? }\end{array}$} & 1. Melakukan suatu hal dengan senang hati \\
\hline & $\begin{array}{l}\text { 2. Memiliki hati yang mau menerima kritik } \\
\text { dan saran }\end{array}$ \\
\hline & 3. Tetap mengucap syukur kepada Tuhan \\
\hline & 4. Rendah hati \\
\hline
\end{tabular}

Dari wawancara dan observasi terhadap 5 partisipan yang dalam tabel tersebut, dapat diuraikan bahwa solusi tentang penderitaan orang yang bersungutsungut adalah: melakukan suatu hal dengan senang hati, memiliki hati yang mau menerima kritik dan saran, tetap mengucap syukur kepada Tuhan, dan rendah hati. Berdasarkan hasil penelitian tersebut dapat dianalisa lebih dalam lagi adalah melakukan suatu hal dengan senang hati, memiliki hati yang mau menerima kritik dan saran, tetap mengucap syukur kepada Tuhan, dan rendah hati sehingga seseorang dapat miliki hati yang mau dibentuk oleh Tuhan.

Diakui bahwa hati itu penting, dan karena itu hati yang suci (Mzm. 51: 12; Yeh. 36: 26) memperoleh makna metaforis untuk sesuatu yang paling berharga dan paling baik. Hati juga sebagai tempat kedudukan emosi (1 Raj. 8-38), ingatan (1 Raj. 4: 29) dan kebijaksanaan (1 Raj 3: 12) NRSV memilih mind "pikiran", dari pada hati. ${ }^{13}$

Dengan demikian dapat disimpulkan bahwa semua emosi manusia kedudukan Ayub adalah pada hati. Hati memiliki peran yang besar dalam hidup manusia. Hati yang baik dapat menjadikan manusia yang baik

${ }^{13}$ W. R. F Browning, Kamus Alkitab (Jakarta: BPK Gunung Mulia, 2007), 134. dengan emosinya yang baik pula namun hati yang tidak baik akan mempengaruhi emosi yang tidak baik pada manusia itu sendiri.

Dampak bagi GBI KelIR adalah gereja akan mengalami pertumbuhan iman yang baik karena dengan adanya orangorang yang memiliki hati yang mau dibentuk oleh Tuhan. Maka akan berpengaruh atau membawa dampak yang baik bagi gereja di mana orang tersebut digembalakan. Dengan demikian bahwa solusi tentang orang yang bersungut-sungut adalah melakukan suatu hal atau perintah dengan senang hati, memiliki hati yang mau menerima kritik dan saran, tetap mengucap syukur kepada Tuhan, dan rendah hati sehingga ia miliki hati yang mau dibentuk oleh Tuhan. Ada beberapa sikap yang kemungkinan ditunjukkan ketika seseorang dihadapkan pada masalah, penderitaan, kesulitan, kesukaran atau kesesakan adalah: Pertama, kecewa, mengeluh, mengomel dan bersungut-sungut kepada Tuhan. Lalu mereka akan membandingbandingkan dengan keadaan orang-orang di luar Tuhan yang membuatnya merasa iri hati. Pemazmur mengingatkan, "Jangan marah karena orang yang berbuat jahat, jangan iri hati kepada orang yang berbuat curang; sebab mereka segera lisut seperti 
rumput dan layu seperti tumbuh-tumbuhan hijau. Percayalah kepada TUHAN dan lakukanlah yang baik, diamlah di negeri dan berlakulah setia" (Mzm. 37:1-3). Sikap membanding-bandingkan keadaan ini juga dilakukan oleh bangsa Israel ketika berada di padang gurun. "Mengapakah TUHAN membawa kami ke negeri ini, supaya kami tewas oleh pedang, dan isteri serta anakanak kami menjadi tawanan? Bukankah lebih baik kami pulang ke Mesir?" (Bil. 14:3) dan "Kita teringat kepada ikan yang kita makan di Mesir dengan tidak bayar apaapa, kepada mentimun dan semangka, bawang prei, bawang merah dan bawang putih. Tetapi sekarang kita kurus kering, tidak ada sesuatu apapun, kecuali manna ini saja yang kita lihat" (Bil. 11:5-6). Kedua, meninggalkan Tuhan. Karena terbentur masalah ada banyak orang Kristen yang tidak lagi bersungguh-sungguh mengikut Tuhan, berani menyangkal iman dan akhirnya meninggalkan Tuhan. Mereka tergiur dengan tawaran-tawaran dunia yang memberi solusi untuk masalahnya. Demas memilih untuk meninggalkan pelayanan hanya karena ia tidak tahan dengan kesulitan dan penderitaan, dan memilih untuk kembali kepada dunia. "...Demas telah mencintai dunia ini dan meninggalkan aku. Ia telah berangkat ke Tesalonika" (2 Tim. 4:10). ${ }^{14}$ Ketiga, singkirkan bersungut-sungut. Dalam Yakobus 5: 9, "Saudara-saudara, janganlah kamu bersungut-sungut dan saling mempersalahkan, supaya kamu jangan dihukum. Sesungguhnya Hakim telah berdiri di ambang pintu". Bersungut-sungut berkaitan dengan iman. Bersungut-sungut adalah tanda tidak percaya kepada Tuhan.

\footnotetext{
14“'Sikap Menghadapi Penderitaan", http://airhidupblog.blogspot.com/2018/06/sikapmenghadapi-penderitaan.html.
}

Seseorang tidak percaya kepada pengaturan Tuhan atas hidupnya, atas cara dan waktu Tuhan baginya. Alih-alih mengambil waktu untuk merenung dan berdoa, seorang yang bersungut-sungut malah sibuk menyalahkan Tuhan atau mengambinghitamkan orang lain. Tidak ada kebaikan dari sikap seperti ini. Cara mengatasi bersungut-sungut adalah bersabar. Bersabar seperti petani menantikan datangnya hujan atau panen. Bersabar adalah teladan yang ditunjukkan para nabi. Mereka bersabar dalam penderitaan karena berpengharapan kepada Tuhan. Bahwa Tuhan pasti akan turun tangan menolong mereka. Waktunya pasti akan tiba. Demikian juga Ayub memberikan teladan kesabaran. Tak sekalipun Ayub bersungutsungut meskipun ia sangat menderita. Atas kesabarannya, Tuhan memberkati berlimpah, mengganti berlipat hartanya yang lenyap. Tuhan tidak pernah membiarkan kesabaran kita tanpa balasan, "karena Tuhan maha penyayang dan penuh belas kasihan" (Yak. 5:11). ${ }^{15}$

Sementara mengapa sampai ditekankan berulang kali oleh Musa bahwa Tuhan mendengar sungut-sungut Israel? (1) Tuhan hendak menyampaikan bahwa Ia tahu segala sesuatu dan tidak ada yang tersembunyi sekalipun itu hanya dikatakan di dalam hati mereka. (2) Tuhan hendak memberitahu kepada umat-Nya bahwa ia tidak berkenan akan sikap bersungut-sungut mereka. (3) Tuhan rindu supaya orang Israel tidak bersungut-sungut dalam hati dan di antara sesamanya sebab adalah kehendakNya supaya manusia terus mengingat segala kebaikan-Nya dan hidup dengan hati yang penuh ucapan syukur setiap waktu. (4) Tuhan rindu mendengar dari manusia suatu

15“ Singkirkan bersungut sungut”, https://hokimtong.org/365-renungan/singkirkanbersungut-sungut/. 
ucapan-ucapan yang berisikan suatu kepada dia dan kepada sekeliling hdupnya. pernyataan iman, pengharapan, dan kasih

\section{Solusi tentang Penderitaan Orang yang Bertengkar}

Tabel 2 Solusi tentang Penderitaan Orang yang Bertengkar

\begin{tabular}{|c|l|}
\hline Fokus & \multicolumn{1}{|c|}{ Sub Fokus } \\
\hline Bagaimanakah & 1. Jangan merasa selalu benar \\
\cline { 2 - 2 } $\begin{array}{c}\text { solusi tentang } \\
\text { penderitaan }\end{array}$ & 2. $\begin{array}{c}\text { Meminta maaf terlebih } \\
\text { dahulu ketika bersalah }\end{array}$ \\
\cline { 2 - 2 } $\begin{array}{c}\text { orang yang } \\
\text { bertengkar }\end{array}$ & 3. Belajar mengalah \\
\cline { 2 - 3 } & 4. Mau mendengar nasihat \\
\hline
\end{tabular}

Dari wawancara dan observasi terhadap 5 partisipan yang dalam tabel tersebut, dapat diuraikan bahwa solusi tentang penderitaan orang yang bertengkar adalah adalah: jangan merasa selalu benar, meminta maaf terlebih dahulu ketika bersalah, belajar mengalah, dan mau mendengar nasihat.

Misalnya hal tersebut bukan hanya gereja yang dipermalukan, tetapi TUHAN pun turut dipermalukan atas setiap pertikaian yang terjadi di antara sesama umat ALLAH. Segala usaha harus dibuat untuk menyelesaikan masalah di antara anggota jemaat dan menyimpan pertentangan itu sedapat mungkin di dalam lingkup yang terkecil. Pertikaian, konflik, dan perkara hukum antara saudara seiman adalah satu cela bagi kebenaran. Mereka yang melakukan hal ini membuka jemaat terhadap cercaan musuh-musuhnya dan menyebabkan kuasa kegelapan menang. Mereka menusuk kembali luka Kristus dan mempermalukan Dia secara terbuka. Dengan mengabaikan wewenang jemaat mereka menunjukkan perlawanan terhadap Allah, yang memberikan wewenang pada jemaat. ${ }^{16}$ Karena itu diperlukan beberapa hal adalah: Pertama, komunikasi adalah faktor

\footnotetext{
${ }^{16}$ Ellen G. White, Testimonies, Vol. 5
} (California: Pasific Press Publishing, 1948), 242-243. penting di dalam kehidupan bersosial. Dengan komunikasi yang baik memampukan manusia berinteraksi yang baik dengan orang lain. Komunikasi juga mampu menolong manusia untuk menghadapi Konflik-Konflik yang sedang terjadi. Namun sebaliknya, komunikasi yang tidak baik dapat menjurus kepada berbagai konflik yang dapat terjadi. ${ }^{17}$ Kedua, tidak bisa menerima kenyataan dengan apa yang sedang dialami. Ketiga, pemberontakan kepada Tuhan. Keempat, kurang bersyukur, dan kelima, kurang damai sejahtera di dalam diri. Dengan demikian bahwa iman seseorang menjadi mati dan kepercayaan seseorang selalu dipertanyakan.

Lebih tajam lagi bila terjadi pertengkaran di antara jemaat maka Vincent memberi arahan agar tidak salah mengalami keputusan melalui tabel Perbedaan Pengelolaan konflik berikut. ${ }^{18}$

\footnotetext{
${ }^{17}$ Wiryanto, Pengantar Ilmu Komunikasi (Jakarta: Grasindo, Gramedia, 2001), 5.

${ }^{18} \mathrm{M}$. R. Vincent, Word Studies in the New Testament (Virginia: Mac Donald Publishing Company. 1888), 722.
} 
Tabel 4. Perbedaan Pengelolaan Konflik

\begin{tabular}{|l|l|l|}
\hline No & Cara Dunia & Cara Allah \\
\hline 1 & Destruktif konflik & Konstruktif konflik \\
\hline 2 & Perselisihan & Berdamai \\
\hline 3 & Mencari menang atau kalah & Menuntut kepada kemenangan \\
\hline 4 & Memilih untuk memihak & Mencari perdamaian \\
\hline 5 & Melebih-lebihkan perselesaian & $\begin{array}{l}\text { Berbicara kebenaran dalam } \\
\text { kasih }\end{array}$ \\
\hline 6 & Diakhir dengan kepentingan & Diakhir dengan makna \\
\hline 7 & Motivasinya menjatuhkan & $\begin{array}{l}\text { Motivasinya melakukan yang } \\
\text { benar }\end{array}$ \\
\hline 8 & Ada agenda yang tersembunyi dari tindakan & $\begin{array}{l}\text { Bertindak dengan jujur dan } \\
\text { terbuka }\end{array}$ \\
\hline 9 & Menuju peperangan & Mengerjakan atau mengolah \\
\hline 10 & Sukar untuk diselesaikan & Mudah untuk diselesaikan \\
\hline
\end{tabular}

Penelitian Tarakia tentang konflik di jemaat gereja ditemukan bahwa:

Pertama, konflik tidak hanya terjadi di dunia sekuler, tetapi sudah masuk ke dalam kehidupan umat-umat ALLAH di dalam gereja.

Kedua, penyebab konflik masuk ke dalam gereja adalah orang-orang yang menjadi anggota gereja adalah orang-orang berdosa, yang memiliki keinginan, motivasi dan agenda yang tidak sejalan satu dengan yang lain, namun disaat melayani pekerjaan TUHAN semua keinginan, motivasi, dan agenda pribadi itu tidak tanggalkan tetapi justru dipaksakan.

Ketiga, umat ALLAH harus mengantisipasi dengan sebaik-baiknya setiap hal-hal yang dapat membawa kepada konflik diantara satu dengan yang lain atau satu kelompok dengan kelompok lainnya, namun jika konflik itu sudah terjadi maka perlunya kerja sama dengan Gembala, Penatua jemaat untuk dapat mengelola konflik itu agar menjurus kepada penyelesaian yang sesuai dengan cara ALLAH.
Keempat, tanggung jawab setiap umat ALLAH untuk menjadi pembawa damai dalam setiap konflik yang terjadi, karena Yesus Kristus telah mendamaikan manusia lebih dulu dan mempercayakan tugas pendamaian itu kepada semua yang percaya kepada-Nya. ${ }^{19}$

\section{Solusi tentang Penderitaan Orang yang Bertengkar di GBI KelIR Samarinda}

Persungutan dalam penderitan dikarenakan: tidak bisa menerima kenyataan dengan apa yang sedang dialami, pemberontakan kepada Tuhan, kurang bersyukur, dan kurang damai sejahtera di dalam diri.

Beberapa tokoh Alkitab yang hidup menderita dan dapat menerima kenyataan hidup, taat kepada Tuhan, selalu bersyukur, dan selalu rindu hidup damai sejarah adalah Daud, Ruth, dan Ayub. Meskipun hidupnya diterpa penderitaan hebat tetapi ia selalu berhasil menyelesaikannya sebagai berikut:

\footnotetext{
${ }^{19}$ Gerry C. J. Takaria, "Mengelolah Konflik yang Terjadi di antara umat Tuhan", Jurnal Koinonia, 8(2), Oktober 2014, 60.
} 
Pertama, Daud, salah satu tokoh besar Alkitab yang mengalami depresi yang cukup besar. Dia mengalami masa yang sangat sulit dalam hidupnya. Dia melarikan diri dari Raja Saul karena ancaman bahwa dirinya akan dibunuh. Di sebagian besar bagian kitab Mazmur, banyak keluhankeluhan dan keadaan Daud yang sangat putus asa. Dia memakai kata-kata seperti kewalahan, beban berat, tertunduk, terganggu, masalah dan kematian. Kata-kata menggambarkan bahwa keadaannya tampak sangat mengerikan. Tapi di beberapa bagian, Daud tetap mengingat bahwa Tuhan itu adalah sumber harapan. Dari Daud mendapat pelajaran adalah bagaimana manusia perlu mengingatkan dirinya sendiri akan janji-janji Tuhan saat dalam keadaan depresi. Walaupun ia merasa keadaan tidak akan jauh lebih baik, tetapi ia bisa mengingat bagaimana Tuhan datang di masa lalu dan tidak akan pernah mengecewakannya.

Kedua, Rut, salah satu sosok yang mengalami depresi atau putus asa. Masa sulit yang dialami Rut dimulai sejak kematian suaminya (Rut 1: 5). Sejak itu dia mengalami kesulitan secara ekonomi. Setelah itu, dia harus mendengar ibu mertuanya memutuskan untuk meninggalkan Moab dan kembali ke tanah kelahirannya. Tanpa suami dan harus meningalkan tanah kelahirannya dengan seorang wanita tua. Bayangkan betapa berat beban yang dipikul oleh Rut saat itu. Rut menghadapi keadaan yang sangat menakutkan. Di negeri asing tanpa suami, dia tak bisa melakukan apa-apa selain menangis dan meratap. Sayangnya, dia memutuskan untuk melayani ibu mertuanya. Pada akhirnya, Tuhan hadir dan memberikati dia. Dia bahkan bertemu dengan suami keduanya dan mereka hidup sangat bahagia. Saat dalam keadaan sulit, Rut tidak langsung melihat Tuhan akan menyediakan hal yang baik baginya. Tapi justru dengan menghadapi dan melewati masa itu dengan setia, dia mendapati hal yang tak terduga di depan. "Sebab itu marilah kita, oleh Dia, senantiasa mempersembahkan korban syukur kepada Allah, yaitu ucapan bibir yang memuliakan nama-Nya" (Ibr. 13:15).

Ketiga, Ayub, dapat menyelesaikan penderitaan yang dialami tanpa memberontak kehendak Allah. Sumber pembelajaran yang sangat berharga tentang realita kehidupan yang komprehensif, karena bukan saja memunculkan sudut pandang manusia tetapi juga perspektif surga yang ternyata tidak pernah kehilangan kontrol atas peristiwa-peristiwa dalam dunia ini. Ayub kehilangan harta kekayaannya (Ibr. 1:13-22), Ayub kehilangan keluarga, dan Ayub kehilangan kesehatannya (Ibr. 2:7-10). Penderitaan Ayub semakin mendalam ketika isterinya turut menghina kesetiaannya kepada Allah. Wanita yang tidak pernah disebutkan sebagai "milik" Ayub sejak awal narasi ini berkata: "masih bertekunkah engkau dalam kesalehanmu? Kutukilah Allahmu dan matilah!" Penyakit yang diderita Ayub sebenarnya menyerang bagian dalam dan biasanya dikenal sebagai penyakit kutukan dari dunia supra alamiah. Penyakit jenis ini tidak diketahui penyebabnya. Orang-orang hanya tahu dari gejalanya yang membuat si penderita tidak berdaya. Ayub memilih untuk tetap berserah kepada Allah yang tidak ia mengerti. Ia masih menyimpan iman yang bergantung penuh kepada Allah; apapun yang terjadi Allah adalah baik, apapun yang terjadi Allah berhikmat sempurna dalam tindakannya, apapun yang terjadi Allah tidak akan meninggalkan anak-anak-Nya seorang diri, 
Ia ikut duduk bersama-sama dengan mereka dalam penderitaan dan air mata. ${ }^{20}$ Dari Ayub dapat mengertian adalah belajar untuk tidak bergantung pada keadaan, tetapi tetap dan teguh memilih untuk percaya kepada rencana Tuhan.

Begitu juga Abraham, Nuh, dan Saulus yang hidupnya selalu mensyukuri, bergantung, dan percaya kepada Tuhan misalnya: Pertama, Abraham, dikenal sebagai "Bapa Abraham" yang merupakan Bapa segala bangsa. Ia dikenal sebagai orang yang sangat beriman dan mau melakukan apapun yang diperintahkan oleh Allah. Salah satunya ialah saat menyerahkan anaknya yang tunggal sebagai korban bakaran. Ia tidak keberatan untuk melakukannya, tetapi Allah tidak tega melihat Abraham. Akhirnya Ia menyuruh Abraham untuk mengambil anak domba sebagai korban bakaran alias persembahan. Dari karakter Abraham yang turut dan patuh terhadap Allah dapat diambil pelajaran adalah selalu percaya, melakukan perintah, dan hidup sesuai tujuan hidup berfokus kepada Tuhan.

Kedua, Nuh, berarti "Imanuel" benar-benar ada dalam dirinya saat membangun sebuah bahtera yang membuat dirinya dan keluarganya selamat. Orang percaya diajarkan untuk selalu meniru karakter Nuh. Pelajaran yang dapat diambil adalah Nuh orang yang percaya, melakukan keinginan Allah tanpa pamrih, selalu menjadi anak Allah dan mengikat janji setia kepada-Nya.

Ketiga, Saulus, yang awalnya, tidak percaya kepada Tuhan. Ia sangat membenci

\footnotetext{
${ }^{20}$ Wanta Sinurat, "Studi Alkitab: Belajar, Menggali, Merenungkan \& Melakukan kebenaran Firman Tuhan", http://www.studialkitab.com/2010/02/di-rumah-bapaku-banyak-tempat-tinggal.html.
}

semua pengikut Tuhan Yesus. Ia melakukan pembantaian kepada umat yang ketahuan mengikut Yesus. Hingga pada suatu saat, ketika dalam perjalanan ke Damaskus. Tibatiba Yesus menampakkan diri kepadanya melalui sebuah sinar. Sinar tersebut sangat terang, hingga membuat Saulus buta pada saat itu. Setelah kejadian tersebut, akhirnya ia bertobat. Pelajaran yang dapat dipetik adalah pertobatan dan menjadi percaya kepada-Nya. Bahkan Paulus (yang tadi Saulus) menjadi orang yang memberitakan Injil ke pelosok dunia. 


\section{Pendidikan Penderitaan dalam Kitab Ayub Memberi Solusi Perkara-perkara Dunia Pelayan Tuhan di GBI KelIR Samarinda}

Tabel 3. Pendidikan Penderitaan dalam Kitab Ayub Memberi Solusi

Perkara-perkara Dunia Pelayan Tuhan di GBI KelIR Samarinda

\begin{tabular}{|l|l|}
\hline \multicolumn{1}{|c|}{ Fokus } & \multicolumn{1}{c|}{ Sub Fokus } \\
\hline Bagaimanakah pendidikan \\
penderitaan dalam kitab Ayub \\
memberi solusi perkara-perkara \\
dunia pelayan Tuhan di GBI & Tetap bertahan \\
\cline { 2 - 2 } KelIR Samarinda f5 & Menyadari Allah adalah sumber hidup \\
\cline { 2 - 2 } & $\begin{array}{l}\text { Jengan menyalahkan siapapun } \\
\text { dan tidak semuanya adalah berasal dari dosa. }\end{array}$ \\
\hline
\end{tabular}

Dari wawancara dan observasi terhadap 5 partisipan yang dalam tabel tersebut, dapat diuraikan bahwa solusi tentang penderitaan orang yang bertengkar adalah adalah: tetap bertahan, menyadari Allah adalah sumber hidup, jangan menyalahkan siapapun, dan menyadari bahwa penderitaan itu adalah sebuah ujian dan tidak semuanya berasal dari dosa. Dengan demikian solusi pendidikan penderitaan yang diberikan kepada jemaat adalah: (1) Pendidikan tetap Bertahan, (2) Pendidikan Menyadari Allah adalah Sumber Hidup, (3) Pendidikan Jangan Menyalahkan Siapapun, dan (4) pendidikan "menyadarkan bahwa penderitaan adalah sebuah ujian dan tidak semuanya berasal dari dosa.

Perlu terjadi proses pendidik penderitaan kepada jemaat agar jemaat dapat bertahan dalam segala kesulitan hidup. Dalam Kitab Amsal 22:6 dikatakan: "Didiklah (Hánök) orang muda menurut jalan yang patut baginya, maka pada masa tuanya pun ia tidak akan menyimpang dari pada jalan itu." Dalam bahasa Ibrani kata Hának berarti to educate, to train, berasal dari arti kata dedicate atau conserete. Dalam Amsal 22:6 dikatakan "Didiklah orang muda melalui jalan yang patut baginya."
Kata hanak berarti to train up atau dedicate adalah verb qal imperative masculine singular. Dengan demikian merupakan proses menjadikan sesuatu dari bawah ke atas. Proses tersebut adalah perintah (imperative) yang wajib dilakukan sekarang juga dan ada hukuman bila tidak melakukannya. Perintah tersebut ditujukan kepada individu (singular). Perintah tersebut ditujukan kepada the boy; youth. Konteks tersebut tunggal, yaitu fokus pada setiap pribadi (the boy). Selanjutnya adalah tenses imperative. Dalam hal ini, to train adalah perintah yang wajib dilakukan oleh the boy yang dipilih sebagai yang to train up (objek didikan). Bagi orang Yahudi, pendidikan adalah segalanya (orang-orang pandai dunia, banyak dari Yahudi). Pendidikan adalah perintah Allah untuk to train up seseorang. Dalam hal ini, to train up mendasarkan Taurat Allah sebagai kurikulum inti yang menjadikan pertumbuhan nilai-nilai pembentukan kognitif, afektif, dan psikomotoris seseorang. Taurat dan semua Hukum, bagi orang Yahudi, adalah lebih manis daripada madu (Mzm. 119:103; Yeh. 3:3). Biasanya, para guru mengambil hati peserta didik dengan memberikan insentif 
berupa manisan (permen), tetapi Taurat lebih manis daripada madu. ${ }^{21}$

Contoh pendidikan yang terbaik dan tidak ada yang bisa menandingi adalah Yesus Kristus sendiri. Yesus sebagai tokoh yang sangat kontroversial: Yesus sering berbenturan dengan para pemimpin agama dan tokoh-tokoh yang merasa dirinya sebagai para penjaga Taurat, seperti orangorang Farisi, dan para penjaga Bait Suci, seperti orang-orang Saduki, namun dekat dengan orang yang dibuang, dilecehkan, dan orang berdosa. Peristiwa hebat yang dialami oleh Yesus menjadi contoh proses pendidikan di mana Yesus sendiri menjadi teladan yang mengajarkan bahwa penderitaan menjadi proses pendidikan yang harus dipaham dan diterapkan dalam mengatasi berbagai penderitaan. Yesus mengajarkan berbagai pendidikan penderitaan dalam menghadapi hidup di tengah-tengah dunia.

Yesus Kristus, dialah Sang Juru Selamat yang datang ke dunia untuk membebaskan manusia dari belenggu dosa. Ia adalah anak Allah dengan wujud setengah Allah, setengah manusia. Banyak dari kamu sudah mengetahui bagaimana karakter Yesus sendiri. Baik, pemurah, pengampun, penyabar, dan masih banyak lagi. Ia memiliki semua sifat yang dimiliki oleh manusia biasa. Namun, sosok ke-Ilahian juga senantiasa ada di dalam diri-Nya. Apa saja yang dilakukan Yesus selama masa hidupnya?

\section{KESIMPULAN}

Pendidikan penderitaan adalah pendidikan untuk hidup di tengah dunia. Manusia sebagai ciptaan Allah tetap menerima setiap penderitaan yang datang dalam kehidupannya. Penderitaan yang manusia alami bukan saja hanya karena dosa tetapi merupakan ujian dari Tuhan agar manusia mengetahui keagungan Tuhan Allah.

Solusi tentang penderitaan orang yang bersungut-sungut adalah: melakukan suatu hal dengan senang hati, memiliki hati yang mau menerima kritik dan saran, tetap mengucap syukur kepada Tuhan, dan rendah hati.

Solusi tentang penderitaan orang yang bertengkar adalah adalah: jangan merasa selalu benar, meminta maaf terlebih dahulu ketika bersalah, belajar mengalah, dan mau mendengar nasihat.

Solusi tentang penderitaan orang yang bunuh diri adalah seseorang berani hidup menderita dan dapat menerima kenyataan hidup, taat kepada Tuhan, selalu bersyukur, dan selalu rindu hidup damai sejarah.

Pendidikan penderitaan dalam kitab Ayub memberi solusi perkara-perkara dunia pelayan Tuhan di GBI KelIR Samarinda adalah memberi kepada jemaat adalah: Pendidikan tetap Bertahan, Pendidikan Menyadari Allah adalah Sumber Hidup, Pendidikan Jangan Menyalahkan Siapapun, dan Pendidikan "menyadarkan bahwa penderitaan adalah sebuah ujian dan tidak semuanya berasal dari dosa".
${ }^{21}$ Harianto GP, Teologi PAK (Yogyakarta: Andi, 2017), 1. 


\section{DAFTAR PUSTAKA}

"Singkirkan bersungut sungut", https://hokimtong.org/365renungan/singkirkan-bersungutsungut/.

"Sikap Menghadapi Penderitaan", http://airhidupblog.blogspot.com/201 8/06/sikap-menghadapipenderitaan.html.

Alwi, Hasan. Tata Bahasa Baku bahasa Indonesia. Jakarta: Balai Pustaka, 2003.

Browning, W. R. F. Kamus Alkitab. Jakarta: BPK Gunung Mulia, 2007.

Davis, Ron Lee. Gold in the Making. Thomas Nelson, Nashville, 1983.

Ezra, Jakoep. Success Through Character. Yogyakarta: Andi, 2006.

Ferguson, Sinclair B. dan Wright, David F. New Dictionary of Theology. Malang: Literatur SAAT, 1991.

GP, Harianto. Teologi PAK. Yogyakarta: Andi, 2017.

GP, Harianto. Teologi Pastoral. Yogyakarta: Andi, 2019.

Groome, Thomas H. Pendidikan Agama Kristen. Jakarta: BPK Gunung Mulia, 2011.

M., Fengky. Masalah adalah Berkat. Jakarta: IGM, 2005.

Maxwell, John C. Mengembangkan Kepemimpinan di dalam Diri Anda. Jakarta: Binarupa Aksara, 1995.

Moleong, Lexy J. Metodologi Penelitian Kualitatif. Bandung: PT Remaja Rosdakarya, 2008.

Pazmino, Robert W. Fondasi Pendidikan Kristen: Sebuah Pengantar dalam Perspektif Injili. Jakrta: BPK Gunung Mulia, 2012.

Sinurat, Wanta. "Studi Alkitab: Belajar, Menggali, Merenungkan \& Melakukan kebenaran Firman Tuhan", http://www.studialkitab.com/2010/0 2/di-rumah-bapa-ku-banyak-tempattinggal.html.
Sugiyono. Memahami Penelitian Kualitatif. Bandung: Alfabeta, 2008.

Takaria, Gerry C. J. "Mengelolah Konflik yang Terjadi di antara umat Tuhan", Jurnal Koinonia, 8(2), Oktober 2014, 60.

Vincent, M. R. Word Studies in the New Testament. Virginia: Mac Donald Publishing Company. 1888.

White, Ellen G. Testimonies, Vol. 5 (California: Pasific Press Publishing, 1948), 242-243.

Wiryanto. Pengantar Ilmu Komunikasi. Jakarta: Grasindo, Gramedia, 2001. 